\title{
THEORETICAL ASPECTS OF THE RESEARCH TO THE CAPACITY OF THE SECURITY SYSTEM FROM THE SYMBOLIC APPROACHES
}

\author{
Zoran Milosavljević \\ Institute for Political Studies in Belgrade \\ Jovan Krstić \\ Association of Public Prosecutors of Serbia
}

The Symbolic Approach to Security System Reform (SSR Symbolic Policy Capacity Building) is a set of ideas and concepts that sends a clear message to the environment that Serbia has broken with authoritarian regimes and their corresponding security systems of the past. As an illustration of the epochal meaning of this approach, the laborious and, based on the latest events, largely incomplete reform of the security services in Pakistan can be used. One of the tasks of social science is making a global assessment on the situation of Human Security. The United Nations has to address it, but our nation needs a serious reconsideration of Common Values (the general security values to be protected) and Public Interest (so called policy of persecution). Why? Because the interest of the citizens is generally neglected by the bureaucracy by prioritizing the interests of various collectives from the state itself to the interest groups, political parties across the country (that same bureaucracy). Concept of the Economic Security is weak (although the most important, including freedom of the market, environment protection, protection of consumers etc.) because we have no long-term Development Strategy, which would be the basis of good Security Culture. If we consistently consider a system and security as such, we note that something is missing in the list of protected property, as priorities, the lack of protection of certain human rights in the corpus iuris of Human Rights (specifically the right to equal access of citizens to private property and private enterprise). But if you believe in such a generally accepted definition of protected resources, and just think of the national economy and finance, from this we can conclude that certain political parties, when they were in power, made decisions that were detrimental to national security with impunity.

Key words: Symbolic Approach to Reforms, Institutional Approach, Balancing Democracy, Security State, Democratic State 


\section{Symbolic Approaches}

he Symbolic Approach to System Security Reform (SSR) is a collection of ideas and
concepts which sends a clear message to the environment that Serbia has broken with authoritarian regimes and their corresponding security systems of the past. ${ }^{1}$ For an illustration of how epochal this approach can be, we can use as an example based on recent events, a very hard and largely unfinished reform of the security services in Pakistan. It is harder and more painful, but also historically important process of balancing democracy in Turkey.

At our national level, a bit of research and scientific projects have not contributed enough to all of us, as an active civic public, to reach a better idea of the causes of our own insecurity and achieve greater impact on the public officials (military/police sector of the society) so more is done to reduce apathy and suffering of citizens in relation to a serious threat to the constitutional order and security of the state. But above all, one must know the answer: who is "we"? People who think they are part of a nation should know who they are (!) As "we", we should recognize what is common and what unites us, because it is as important as what each of us needs to know who I am, recognizing "I" as a citizen of their city and their country. The general problem of the level of Security Culture $^{2}$ in societies in transition from the authoritarian past to a stable democracy is that

\footnotetext{
${ }^{1}$ Petar Zeman, "The Transformation of the Intelligence Services," Transformation - Chez Experience, Hugo Printing Company, Prague, 2006, p.115, "The primary task for newly emerging free societies immediately after the defeat or collapse of authoritarian or totalitarian power is to destroy the existing secret police services - it is a task that plays a major role in determining the success of transformation. There are at least two reasons for this. By dissolving their authority, an open society ensures the situation does not turn around and return to the old order, confirming, in a highly symbolic and visible way, its divorce with it before its own public and the world in general. However, in an open society a number of threats that had up to then been hidden beneath the blanket of oppression emerge with an inflationary tendency, the most visible of which is the appearance of new forms of serious crime. The new political elite are faced with the task of building new intelligence and security services (for simplification, I shall use the term secret police from here on) or transform the remains of the old ones almost immediately after the fall of a totalitarian regime..."

${ }^{2}$ Glossary of Security Culture, Centre for Civil-Military Relations, Belgrade 2009, Stajić, Ljubomir S. Mijalković, Sasha and Stanarević, Svetlana. Youth's security culture: how to live safely, Belgrade, 2006: Draganić, Johnston, Alastair I. "Thinking about Strategic Culture," International Security, Vol. 1 9, №4, (1995) Katzenstein, J. Peter Culture of National Security, New York: Columbia University Press, in 1996.

http://www.scribd.com/doc/19945269/pojmovnikbezbednosnekulture. "Security Culture has its own internal and external events. Interior relating to the consideration of security and external security relating to the behavior and the attitude and approach to security, by which is primarily related to the willingness and ability to, any material of any spiritual answers to the challenges and threats. How culture shapes the National Security, is best seen through the behavior of states in international relation, and accordingly, the exercise of such a position from which can significantly affect other countries in the international arena. When viewed / analyzed the sphere of action of Security Culture recognized then, three areas / fields where she often finds use in international relations and to the related fields of political, strategic and organizational culture. In studies of international security is often used precisely the concept of Strategic Culture. According to Jan Alastair Johnston, it can be defined as "an integrated system of symbols, establishing long-term strategic preferences by formulating concepts of the role and efficacy of military force in international relations at showing that the strategic, as well as factual preferences that they look unique realistic and effective ." And Security and Strategic Culture are part of the Political Culture of a political community. Since the time of creation of modern Nation-States, it became clear that culture can be shaped structures and deliberate policy, but it can also be a tool by which people can shape their opinions, prejudices, emotions, behaviors and policy preferences. Unlike
} 
Theoretical Aspects of the Research to the Capacity of the Security System ...

most people have a vague feeling of who they are as citizens and as members of a nation, or a minority group, where they were and where they were headed. The Academy of Arts and Sciences, the Church, all of what is considered the social elite, the Government and non-governmental organizations, the powerful media that have risen to the highest authority in the community (with the TV studios of which Hollywood would be envious), do not give the correct answer to the citizens of Serbia.

How wouldn't it be, when a large number of citizens of the Republic of Serbia do not recognize themselves in the vision of the nation and globalization provided by TV series "My Cousin from the Country" with the ambitious slogan: The major role is played by Serbia! Therefore, the main security problem is that many citizens do not participate in public political life or resist accepting different standards and in that way similarly proclaimed social values, as they generally do not recognize themselves as subjects of national security.

Profiling of the National Legislative Framework and National Political Framework in this area is based on the sense of individual and general uncertainties within the natural state of insecurity and unpredictability. One of the tasks of the social sciences is to make a global assessment of the state of Human Security. The United Nations has addressed the theme, but on our national level we need serious review of the common values (the General Security Object of Protection to be built) and interest (so-called the General Policy of Persecution to meet the people's needs in this area). Why? Because the interests of citizens is typically neglected by the bureaucracy in the favour of the various collectives, ranging from interest groups across the political parties to the State itself (i.e., to that very same bureaucracy).

Previous studies have led to the development of many new Security Concepts, which sought to explain the new Security Reality, and one of the new key notions for understanding our Real Security and, in a way, the global awareness, is the notion of Human Security. Human Development Report of the UNDP in 1994 explains the concept of Human Security as "the universal human focused concern for human life and dignity." It defines seven Categories of Human Security: Economic Security, Food Security, Health Security, Environmental Security, Personal Security, Political Security and Community Safety.

Essentially, the Capacity of the Security System, or an extent of protection provided by the system, does not refer to it as our national profile in the field of building security system enough civilian controlled and effective enough to protect society and derive some additional capacity to the global security, but refer to whether the national profile is

\footnotetext{
the political, strategic and organizational culture, Safety Culture should allow to determine the behavior of some security in the system as a whole, its individual parts within a particular group (subculture), as well as the security key point's initiatives and decision-making at the level of state or any other entity. Culture and Code of Conduct of security are changing, evolving and becoming more complex in accordance with the changed role of the state and the change of the security area / environment inside or outside the state territory / territories."; Stajić, Ljubomir S., Mijalković, Sasha and Stanarević, Svetlana. Youth's security culture: how to live safely, Belgrade: Draganić, 2006th Johnston, All Star "Thinking about Strategic Culture," International Security, Vol. 19 , No4 (1995); Katzenstein, Peter J., ed. Culture of National Security, New York: Columbia University Press, in 1996;

${ }^{3}$ UN Development Programme (UNDP). UN Human Development Report, New York: Oxford University Press, 1994, p. 3;
} 
narrower than desired profile of Human Security by the standards offered by international organizations such as $\mathrm{DCAF}^{4}$ (and their Code of Ethics Politico-Military Aspects of Security $^{5}$ ) and the RAND Corporation and their leading ideologue ${ }^{6}$ (by the Report prepared for the Advisory Team for Security Sector Reform in Great Britain ${ }^{7}$ ), in order not to repeat the case of the inadequacy and ineffectiveness of National Security System ${ }^{8}$ such as in the case of NATO's intervention in the former Yugoslavia ${ }^{9}$. There is no security system that is self - sufficient and that evens the global one, nor can it be copied. Security Systems that are assessed as these mentioned have been insufficient measured by some standards and should be established as autonomous in relation to the other precisely because of their capacity expansion, in the sense that in order to avoid the suffering outside intervention caused by the incompatibility, or if it ever comes to the international intelligence community being authorized to influence the appropriate way in terms of reforms. Otherwise there is a danger of the international instruments of control over the UN and their standards to be administered inappropriately by saying: "If all of you have a hammer, then every problem begins to resemble a nail." ${ }^{10}$ We can show this logic in a simple empiric research:

\footnotetext{
${ }^{4}$ Dimitrijević, Vojin. Social and Cultural Prerequisites for Promotion and Implementation of the Democratic Control of Armed Forces (Working Paper Series N67), Geneva: Centre for the Democratic Control of Armed Forces (DCAF), 2002.

${ }^{5}$ Geneva Centre for the Democratic Control of Armed Forces (DCAF), Occasional Paper - №.11, Implementation of democratic control of armed forces In the OSCE Region: Lessons Learned from the OSCE, Code of Conduct on Politico-Military Aspects of Security, Alexandre Lambert, Geneva, July 2006.

${ }^{6}$ Fukuyama, Francis, The End of History and the Last Man, CID, Podgorica, 1999, claims that the foundation of a new world order "universalization of liberal democracy as the final form of human government," Author's comment: it does not automatically mean that the leading democracy of the Western Countries but "Leading Democracies" around the world with all regional challenges and contradictions (EU, Brazil, India, the U.S., Australia, South Africa, etc.).

${ }^{7}$ Greg Hannah, Kevin A. O'Brien, Andrew Rathmell, Intelligence and Security Legislation for Security Sector Reform, RAND Corporation, Report was prepared for the UK's Security Sector Development Advisory Team, www.rand.org

${ }^{8}$ Matić, Goran, "The Angels of Mercy," MEDIAGRAF, Belgrade, 2005 , p. 344, Author's note: on this statement Matić does not agree;

${ }^{9}$ Annan, Koffi: "Two Concepts of Sovereignty." The Economist, September 18th 1999.

www.un.org/Overview/SG/kaecon.htm> (01/19/2000), In his speech in 1999 and again in his speech in 2001 on the occasion of receiving the Nobel Peace Prize, Mr. Annan supported the idea that the "General Interest of Humanity" has to be in front of the sovereignty of the states. The Secretary-General has argued that the UN armed intervention in support of this General Interest was the only occasion in which the use of force can be justified. Souverenity of states, in the most basic sense, redefines the forces of globalization and international co-operation ... (until) the sovereignty of individuals...increased by revived awareness of the right of every individual to control his own destiny... Massive and systematic violations of human rights, wherever they are going on, cannot be tolerated."

${ }^{10}$ Milosavljević, Zoran T. The role of the global political community in the preservation of world peace," University of Belgrade, Faculty of Political Science, Department of Political Violence and State, Master thesis, Belgrade, 2009. "Often, paradoxically or not, the steps toward the resolution of the dilemma of Human Security occur only after the use of force, mostly military forces of National Security. But such an outcome should not prove to be as true for some of the problems of Human Security in the future (which are created today). Thus, there is a real need for alternative perspectives allow engross one's opinion. They point out that Military Security, especially American analysts and policy makers at the expense of other forms of security, can bring a fundamental paradox of self-sufficiency: When someone using more effort to avoid a military intervention, it is more compelled to intervene militarily due to the inability to recognize the conflicting aspects of security and to
} 
Theoretical Aspects of the Research to the Capacity of the Security System ...

Personal Safety of the citizens in Serbia is not high due to the increasing extremism, which is defined as an extension of man (society) beyond the reach of his limbs (borders) and related conditions such as: blaming someone else, a sense of inferiority, cruelty toward subordinates and servility to the powerful, xenophobia, militant exhibitionism, especially militant extremism "corresponded to times of crisis and intensified to the point of being unbearable." Conclusion is based on the results of a criminal prosecution for offenses involving violence and simple recital of the facts of Hate Speech and Hate Crime, intolerance that breeds conflict from which it follows that at first glance we can see and conclude that the threat to personal safety is much higher than the level in the stable democracies (EU). This is because many citizens do not earn for a decent living, look for work but cannot find it, and many of those having jobs are not able to live off of their work.

Hence, the Security Culture is reduced to simply navigate and rely on "everyone and everything" except the institutions. ${ }^{11}$ From the ground, through the institutional to the outside space, (lack of the) Security Culture manifests itself in the way that is politically assessed by influential international circles as expansionism, ${ }^{12}$ fuelled by certain "government centres expansionism,"13 as a synonym for the tendency to expand on someone else's premises as they may be bounded and as it could be considered a potential threat to world peace, as well as a potential reason for foreign intervention. In this way, our society and the country begin to look like the "nail" mentioned above, by coming under the international criticism of the political attitudes of the Academy of Sciences and Arts, the Serbian Orthodox Church, the Serbian Government and the National Assembly.

deal with them in a preventative manner. Old phrase that describes the trap is also a handy reminder: "If you all have a hammer, then every problem begins to resemble a nail." Certainly, as the intervention in Somalia, the Balkans, Afghanistan and Iraq illustrate, the traditional use of Military Security may not be the best one, and not only one strategic instrument that is applicable."

${ }^{11}$ Maya Bjeloš, "What are the citizens thinking of their own security and the security of Serbia?" BCSP (Belgrade Centre for Security Policy), the Research in Cooperation with CeSID in April and May 2010. They conducted a public opinion survey on the perceptions of citizens on personal, collective and national security. Answering to the question of who is responsible for their personal safety, nearly three-quarters of women (66\%) and men (65\%) do not believe that the state authorities contributed to them to feel safe, but a sense of security as an attribute to their lifestyle, good neighborhood, the environment in which they live or the ability to self-protection. However, answering on the specific question on which institution contributes most to their sense of security, slightly more women (30\%) than men (28\%) said that this is so because the Police, while $5 \%$ of men as at the second place of the importance for their personal security selected by the Military, and only $3 \%$ of women.

${ }^{12}$ Dragan Simeunović, , Definition of extremism from the perspective of political theory, Serbian Political Thought, Vol. XVI Vol 24, №2/2009, p.15; From the abstract: "... The author analyzes a multidisciplinary point of the fundamental characteristics of political extremism, its causes and consequences for the socio-political system. While it is tolerable only as long as marginal in a society, extremism typically corresponded to times of crisis and intensified to the point of being unbearable and unaccepted. Extremism is expressed as a militant exhibitionism for fear of impersonality and ultimately the cancellation of personal identity."

${ }^{13}$ Miroljub Jevtić, S. Orthodoxy and the Serbian National Identity, Serbian Political Thought, 1998, Vol. 5, № 1-4, p. 63-78," Unlike other forms of identification, religious identification has always been a powerful and indivisible. That is why, under the influence of pro-elite churches and expansive government centers in Yugoslavia was particularly difficult inter-cultural rapprochement. Underestimation of religious differences in the formation of the South Slavic Communities and their effect on the slow development of other values and cultural foundations of South Slavic Unity over time has become an important cause of difficulty, crisis and the collapse of two of the Yugoslav states, which in any case deserves more attention in contemporary political studies." 
However, most importantly, the Economic Security (Free Market) is low, because we have no Long-Term Development Strategy, as the foundation of the good Security Culture. What's more, the concept of National (State) Security refers to goods/values that are protected or are under way of becoming such, so the overall protective facility and special protected buildings already obsolete offenses against the security and the constitutional order of the Republic of Serbia in the Criminal Code, and threats that threaten these resources, such as: undermining or weakening of the national economic and financial power. But the real object of protection are natural resources, rather than a political regime, especially in the regime where the market is fraught with monopoly and oppression, which creates a breeding ground for corruption and money laundering, smuggling, and in which the natural resources are exploited without control and social character of the whole national production is not adequately used by society, but the total Gross National Production (GNP) is reduced to oligarchy. Oligarchy creates tycoons - inappropriately wealthy individuals who act uncontrollably and unsafely for the whole of society from the standpoint of the public interest ahead of the specified safety field because they protect their narrow economic interests and criminal activities (e.g. smuggling).

If you consistently consider such a Security System, we see that in the list of protected goods/values, the protection of certain human rights from the corpus iuris of human rights is lacking as a priority (specifically the right to equal access of citizens to private property and private enterprise, not just tycoons). The legislation lacks an anthropocentric kind of norms with environmental constraints (rather than ethnocentric norms with utilitarian extensions to allow tycoons uncontrolled extraction of resources such as sand from rivers, drilling machines for dispensing oil, mineral resources, hunting wild birds, etc.). In our academic circles, there is no supporter of the theory and practice that should shape the Penal Code in such a way that these norms are adorned by an important chapter of the Code, such as specific crimes against the constitutional order, designed in an anthropocentric manner, not state-centric as present, in order to reach a binding contact of our legislative framework with framework of the imaginary world the concept of human security. But if you believe in such a generally accepted definition of protected resources, and just think of the national economy and finance, from this we can conclude that certain political parties, when they were in power, made decisions that were detrimental to national security with impunity. But who is the one that shall forthwith send a message to the Government? The general feeling of the laity is that the public perception of safety is such that it appears that there was no time to stand trial for people who made bad decisions.

Generally, only equal, free, and democratic participation in political and economic life of citizens in the country or community can build national security and contribute to the construction by establishing an integrated security. Only complete Guarantees of Human Rights, participatory governance, the rule of law, sustainable development and equal access to resources can provide the human and national security to contribute to democratic decision-making and international cooperation..$^{14}$

It is the ruling feeling of inadequacy that has coincided and conducted social change in countries in transition, the main empirical evidence of lack of capacity of the Security System. When we analyse the perception of citizens about what they perceive as the

\footnotetext{
${ }^{14}$ Radoslav Gaćinović, "Democracy and Security in the Nation-State", Serbian Political Thought, 2010, № 1, p. 151-168.
} 
Theoretical Aspects of the Research to the Capacity of the Security System ...

main factors endangering National Security, we see that the "voice of the people" (vox populi) indicates that security services are far from the priority, for the citizens put in the first place of danger the so-called " White Plague" (low birth rate) as the main source of existential fear of the population, of course, far ahead of "endangered territorial integrity" which suggests that the media and politicians are far from what citiznes consider to be the most important. In doing so, the female correspondents showed their atavistic security features (intuition), and it is to be sensitive to the risk of loss of people of the matter (substance) ${ }^{15}$, the concept of security just applies to humans, so the personal substance of the state, and not to things belonging to the state.

This resembles the fable of the "Emperor's New Clothes," we are waiting for an innocent boy to announce that "the emperor is naked," ${ }^{16}$ thus, to be in the area of constitutionally guaranteed rights of the people and the security of the state, to demystify the sort of simple distinction between light and darkness, that is, to realize that the democratic transition is not reduced only to giving people just the right to vote as a kind of punishment for the Government for bad conduct of the people and the state, but that it comes down to and summarizes a special kind of criminal responsibility - Historical Responsibility. We have publicly expressed the view that on 5 October 2000 our country has missed a historic opportunity to create a different and a better world. There are courts, but, for now, they are for regular proceedings, because for such a trial they are unprepared, but there are no Courts of History. It is high time to better examine a specific type of judgment based on historical responsibility. The governments in the transition bear a huge load of historical responsibility that has been transferred due to errors committed on behalf of all governments and authorities in the past. So if there is a historical responsibility, and if this responsibility is easiest understood as a simple sum of the results of accumulated political mistakes from the past, then the security of the entire system must be discussed from the point of civilian control from the point of view of the insufficiency and inefficiency - ineffectiveness. There have been many examples in history when governments or rulers apparently had no proper assessment of the degree of vulnerability of the people and the state, or, otherwise, they simply would not have made some wrong decisions, or, if they were aware of the facts, and still made that decision, then why had they not been notified/alarmed by a proper security system? Due to the time passed since the events by which the actors were influenced, among other things, the security services that started avoiding complying with the rules of profession, it is necessary to correct our historical memory.

Judgment of History, therefore, requires the existence of a Historical (State) Memory. But in the Balkans of course, unevenly intertwined and complemented are both our and the EU standards of civilized governing and civilized relation to the past. But, not only in the Balkans, there is present tension "between transnational and EU anti-totalitarian memory of the Holocaust as a symbol on one side and the national memory of the

\footnotetext{
${ }^{15}$ May Bjeloš, "What do Serbian citizens think about their own safety Serbia?" BCSP (Belgrade Centre for Security Policy), in cooperation with CESID, when asked what the main threat to the security of the nation they belong to men and women gave the following answers: "white plague" (insufficient national birth rate) - men $37.2 \%$, women $35.6 \%$," secession of Kosovo and Metohija " - men 19.6\%, women $14.2 \%$, "strengthening nationalism and ethnic tension" - men $11.9 \%$, women $128 \%$, "migration" - men $9.8 \%$, women $10.3 \%$.

${ }^{16}$ Svetislav Basara, 30/09/2009, "Danas" daily, "Basara - the Famous "Emperor's old clothes."
} 
victims, centred around individual communities, on the other hand ${ }^{17}$. Between the various countries in the region and on continents it leads to a kind of "war of memories." Conflicted histories are retroactively the source of conflict. Conflicts of this kind undermine the security of the EU, which has already achieved political unity and seeks to achieve resolution on non-conflict relationship in the past.

The process of reforms of the security services were symbolically based just on the fact that we ended with the authoritarian past. Changes in the field of Civil - Military Relations suggest us to approach slowly and inconsistently, no matter how thoroughly inaccessible to researchers, so that some authors found that nothing had changed. In doing so it is left as it is evident, that the changes in the symbolic values are protected. While a one of the sovereign of Serbia - Tito was derived from the global policy making to socialism bond of brotherhood and unity, today Anti-Titoizam in a multi-party democratic society is the nexus of nationalism. In these considerations it is estimated that the situation is similar in other countries. It is because they are an official memory of all the Eastern European member states socialism labeled as anti - national social system, but not as anti-nationalist system. Shift from an authoritarian past as a measure of progress of societies in transition had serious consequences: extreme nationalism is therefore left without the necessary supervision and control in many countries, including Serbia. That causes a slowing down of the transition and damaging the interests of the safety of citizens and the state.

Capacity of knowledge relating to the real world determines the capacity the security. Reducing the capacity of the security services, there is all the selected wrong symbolically rejoins, for example, rather than anthropocentric social system and the system of law, the corpus of human rights is at the centre of public interest and welfare, as a desirable state, the public expects to achieve through peaceful means. There is impression that the selected ethnocentric system is with the public interest bounded by ethnicity, not to human rights limits. Some intellectuals are "right" when they claim that this is their life, but it is extremely autistic to try to apply their perception to all other citizens of the Republic of Serbia. Dogmatic avantgarde and false consciousness with of the commissar, without any respect for their fellow citizens, the public pays part of the Serbian intelligentsia, primarily members of their own people, using outdated rhetoric of public policy, and it seems now that we are part of global insecurity and probably the subject of the threat of foreign intervention.

In contrast to today's relation of an intelligentsia acting not in accordance with citizens, when Dositej Obradovic came to Serbia in 1806 and also found a huge primitivism, with great wisdom and respect for his own people, he worked on changes in conditions that some chroniclers compared with the "stone age," as described by Milos Obrenovic's hairdresser, whose Dositej in 1811 accidentally saved as a clerk, and not to be executed by his captains. He saw Serbian Dukes acting extremely primitive referred to each other as " giants among men and tigers " Unfortunately for our philosophical and political thought, such an approach to building a Serbian Civil Society after Revolution (1804) which is rightly called The Third Bourgeois Revolution, behind the American Revolution and the French Bourgeois Revolution at the beginning of eighteenth century, the epochal and dignity surpasses our most intelligent heads at the beginning of XXI

\footnotetext{
${ }^{17}$ Todor Kuljić, "Politika daily", 2011, Feuilleton from the broader unpublished studies "Remembering Titoism: long shadows of the past"
} 
century, just when it is necessary only to reestablish middle - class that has yet to bear the burden of epochal change, after being destroyed in socialist revolution.

IN USA the reforms were going on since the establishing of Central Intelligence with warning prediction that we must constantly have in mind "in the global and totalitarian war, intelligence must be global and totalitarian." ${ }^{18}$ In Argentina, the process of reform of the security system lasted and lasted more than 200 years, and only the Law on National Security was enacted in 2001 after twenty years of discussion. ${ }^{19}$ Changes in the security culture in Serbia lasted also since the man of the format of Dositej advised Karađorđe, ${ }^{20}$ and when still not listening to advice "to engage played troops for Serbian heads not to fall", Karađorđe ordered "to move all the gun can handle" having no strong regular army. Then, in response to failures in the fight against Insurgent army, Ottoman Empire learned the safety lessons and decided to abolish the Janissary Army because they assessed "that the empire will collapse...If instead, it does not establish a regular, educated and disciplined army." ${ }^{21}$ And since the first security activities in the territory of Serbia, when they were encouraged by the first intelligence activities described as "double games" or i.e. double engaging agents in Ottoman age ${ }^{22}$ and to this day, when we created the first Serbian Professional Army, then, after suffering enormous loses in a long time when implementing the doctrine of "armed people," ${ }^{23}$ which turned Serbia into a demographic havoc.

National historiography has for a long time argued in the way that the summary is communicated to as following: "Great powers for their own interest used Serbs at the turn of this century and forced them to defend their national identity and statehood. Ekmečic is the first historian who discusses these issues in a broader, five centuries of civilization and national historical context. Active participation of the lone superpower, with the assistance of its satellites, at the time of a one-polar world led to fragmentizing Serbian ethnic area and threatened sovereignty that still continues." ${ }^{24}$ If one accepts that the Serbian people

\footnotetext{
${ }^{18}$ Tim Weiner, Legacy of Ashes - The History of CIA, Doubleday Publishing Group, Random House, Inc. 2007, New York, Chapter 1, p. 3, General William J. Donovan: from the letter addressed to the Us President Roosevelt in November $18^{\text {th }} 1944$,

${ }^{19}$ Thomas, C. Bruneau and Steven C. Boraz, Reforming Intelligence Obstacles to Democratic Control and Effectiveness, Chapter 8 Establishing democratic control of intelligence services in Argentina (Priscila Brandão Carlos Antunes), p. 195;

${ }^{20}$ Andrija BK Stojković, "Life Path Dositeja Obradović," Beletra, Belgrade, Firstly, instead of social utilitarianism bourgeois individuals who Dositej preached in the West, there is a general precedence over personal interest, "Cursed is every one that its loves more the general benefit than his own." His plan puts education where it should be even at that times where there was a war for the preservation of bare life, the right place - and that is the end: after the military, taxes, "the laws of Christians", than comes "establishment of schools."

${ }^{21}$ Resurrection Serbian state: political-historical study of the first Serbian uprising, $1804-1813$, p. 80, p. 13;

${ }^{22}$ Military Security Agency, Chronology of the Security Service in the Army http://www.mod.gov.rs/lat/organizacija/vba/vba_istorijat.php,

${ }^{23}$ Dobrila Gajić-Glisić, "From the office of Minister of War - Serbian army", "Litopapir,"Čačak, 1993 p. 30; "From the statement of the Minister of Defence Tomslav Simović...Public information ", No 1077/91-01 date: 05. 11. 1991; "... today in Belgrade held the first meeting of the Commission for drafting the Law on the Serbian Armed Forces"; Page. 23; "Given that Croatia has already had a mercenary army," the "Boss Jezda" suggested that ... we take from the world of commandos to fight instead of people. Such mercenaries are everywhere in the world and it was not hard to get there. But that was not an option."

${ }^{24}$ Milorad Ekmečić, "The long movement between slaughter and plowing: A History of Serbs in the New Century: 1492-1992, "Belgrade, Textbook, 2007, p. 600, from the display by Staniša Nesić,
} 
living in the territory of where major powers acted for their interests, that the Serbian state was repeatedly a disruptive factor in the territorial and political aspects of security, we certainly have to accept the necessity of the fact that the Serbian people and all citizens must have a secure state, primarily for all, not just only for the Serbian people itself. According to this view of our past and moving into the future, it is necessary to have precisely the wisdom of reformers who would skilfully avoid being judged as an ideological enemy of the church, a party, or any nation, globalization, regardless of anything or anyone, either here, or in the world, just as Dositej Obradović was. The symbolic target of changes is not only a shift from an authoritarian system of government in the past, but also to achieve Dositej's mission in XXI century. Dositej's historical mission is rightly celebrated and evaluated as a creative synthesis of eastern and western cultures on the basis of positive folk tradition, as a synthesis of the contradictions between old and new, ${ }^{25}$ as we still badly need in the area of security that would be re-professionalized and understood as a synthesis of old and new professionalism in relation to convergence.

At the same time, we must bear in mind the scientific criticism of Dositej for "westernization" of Serbia and the Balkans, as "yet another hegemonic approach to transition." ${ }^{26}$ It's not about the revision of historical facts, but to draw lessons from how our past has been seen by others and to see what other safe and peaceful behaviour is expected of our environment. And only then to consider the scientific criticism of Serbian nationalism in public policy starting from Grashanin's Memorandum "Načertanije" to the Memorandum of the members of the group from Serbian Academy of Science and Art in 1986 and conflict that followed the disappearance of the former Yugoslavia in 1992, then the conflict with NATO

\footnotetext{
${ }^{25}$ Andrija BK Sojković, "Life Path Dositeja Obradović," Beletra, Belgrade, "Obradović has avoided the tragic fate of many burned" heretics," although he had opponents especially from the ranks of the clergy. He did not want to be a preacher or apostle of the new religion, which acts as gall old critic like Erasmus, Rabelais, and Voltaire. $\mathrm{He}$ could not stand not conducted any violence - believing in the spirit of the epoch that truth itself paves the roads, and that reform and progress does not come from above, but from below - education and culture."

${ }^{26}$ Fischerm, Vladimir "The Role of Dositej Obradović in the Construction of Serbian Identities During the 19th Century", www.yorku.ca/soiNol_3/_HTML/Fischer.html, "Today, nearly a hundred years after the first centennial of Obradovic's death, what matters is which meanings are now attached to Dositej Obradović. The last struggle over his image took place in 1999 when two of his statues were overthrown in Kosovo. If Albanian activists were behind it, as the Yugoslav press agency claimed, the deed shows that the symbol of Dositej did not lose its hegemonic character in Communist Yugoslavia. It is, of course, not clear which kind of hegemony it stood for: Communist, Serbian national, Western, or for the educational system as such. In the case cited, the Serbian national and the Western hegemonic traits seem to have played a role, as in a clipping from the Yugoslav press agency from September 21, 1999, taken from the homepage of the Serbian Unity Congress. Interestingly, in order to present Yugoslavia as a Western country, Obradović is foregrounded, while "Albanian nationalists" appear as anti-Western outlaws:

NATO aggression against Yugoslavia. New bits Pristina - On Saturday, ethnic Albanian nationalists pulled down a monument to Dositej Obradović, Serbia's enlightener, philosopher and writer, which had been located in front of the Pristina University chancellor's office. Obradovic (1742-1811), author of a large number of works written in Serbian and other languages, established cultural and educational links between the Balkans and Europe, creating a basis for the Serb's modern literature. (...) Since the deployment of the U.N. peacekeeping force KFOR in the province, ethnic Albanian extremists have also pulled down monuments raised in Pristina, the main city in the Yugoslav Republic of Serbia's Kosovo and Metohija province, in memory of Vuk Stefanović Karađić, Serbia's nineteenth-century language reformer, and Petar Petrović Njegoš, Montenegro's nineteenthcentury ruler, poet and bishop. They have also destroyed a monument in Prizren to Emperor Dušan, who ruled Serbia in the thirteenth century, and a monument in Gnjilane dedicated to Emperor Lazar, who died in the battle of Kosovo in 1389 making it impossible for the Turkish army to continue its advance towards Europe."
} 
Theoretical Aspects of the Research to the Capacity of the Security System ...

forces in 1999, the scientific analysis of the legal nature of the "Kumanovo Agreement," and then order the critique of public policy after the political changes of October 5th, 2000. There are three key moments of security system weakness: 1) the release from detention of members of the "Zemun Clan" and mutiny of the Unit for Special Operations (JSO) without armed response of the state, 2) the murder of Prime Minister Zoran Djindjić and a proclaimed State of Emergency and 3) only partially implemented police action "Saber." The list of criticism of public policy does not end here, because after that, there was frustration about rapid accession to the EU and to strengthen the extreme right of Serbia to the fifth cause civil war if we commit errors in Risk Assessment to National Security regarding the danger threatening from extremism, as it seems to have happened in Norway.

Seminars devoted to security system reform and to the application of DCAF standards and its code of ethics amount to the claim that the military and civilian sector does not have enough internal arguments for radical reform if the reform in the professional sense is not significantly different in accordance to the methodology of implementation, the technological changes in a profession. We need reform that by the level of knowledge and wisdom should be exhibited much higher. Some scientific research on alternative development strategies of professional advocacy and advocacy for reforms itself can serve as an example of proper professional approach to reform through a creative blend of the old and the new professionalism. ${ }^{27}$ Awareness of the need for changing one-self, if successful, letting alone a profession as the main motivating factor.

Therefore, we must proceed from self - awareness. But how to get genuine political will of the people, when the political will is constantly falsified by the influence of powerful media, which are said to be under the control of the intelligence services, deliberately said so, because we do not know that and is not scientifically established on facts ? There are only empirical data on the selfish and reckless conduct of Serbian tycoons who own these media, as mismatched as Serbian dukes from the First Serbian Uprising in 1804. It is not a simple reminder and simplified symmetry with a historically and fundamentally different situation. In the circumstances, as used in ancient times to the cobbles on the information highway big Internet, as the rolling elements for our, now broken into pieces and shared collective consciousness, split personality of some politicians, even severe cases solved by political autism, according to some estimates. Their behaviour builds reactions of influential members of the international community who try to find the least painful way to resolve conflicts in the territory of the Balkans. The content of blogs where people comment on public policy is empirically the reference: One blogger as lquique ex populo (of course, so to speak by people, but because blogs are written by intelligence) suggest that it is important that the citizens of Serbian nationality, and the Serbs, above all, stay safe in their daily lives in the places where they live, whatever the political regime and state problems. On the other hand, it should always be borne in mind that the perspective of solving the state problem such as Kosovo and Metohija "depend on complex international geopolitical relations ... and it's designed for NATO to stay much longer Albanians want." 28

\footnotetext{
${ }^{27}$ A new Advocacy Strategies of Professional Value of the Security Services is needed (Comment of the authors).

${ }^{28}$ Dragan Simeunović, "The Battle of Kosovo and Metohija - the history, current situation and perspectives, military action," Military Review, Belgrade, 2000, Vol. 52, /Nº1, p. 16-39.
} 
Previous self-knowledge and self-awareness is a key element of every national and global security system. Globally, the revisionist schools of history strive to provide better and more accurate picture of the past of the world, ${ }^{29}$ and vice versa, to the instrumentation and obscure relativism, or attach the historic responsibility to certain states for violation of global security. For example, in our field, a translation of the book "The Myth of the Holocaust" by Jürgen Graf appeared, which in a very primitive way diminishes the responsibility of the Nazi War Crimes committed on Jews ${ }^{30}$ and contains a unique satanic approach to the history of Western Civilization and Culture. ${ }^{31}$ The media paid attention to prohibit the publication following the template of condemnation of denial of Holocaust as the "cornerstone" of the world and European deflection of war crimes, but failed to publicly condemn the crime in the announcement. It is hoped that the persons twisted in the printing of this publication will be publicly notified that they are under surveillance, and so are we, all other citizens, and we were assured that this is done for our safety in the future! This is dangerous play with translator and interpreter issues (who even gave a press statement appealing to be protected from prosecution as a privately funded edition of translations which is normally printed abroad) is part of far more serious dispute between the European and Russian historiography about the cause of another World War II. ${ }^{32}$ States are trying to fight against changing history, and the influence to change the course of history, ${ }^{33}$ and this should be truth in Serbia.

However, in Serbia, there is revisionist historiography just enough to appreciate this, since it is ignored: for months (books released by authors convicted of organized criminal and war crimes), for years (conflict with NATO in 1999), for decades (People's Liberation Struggle in the WW2 (NOB) and socialist revolution and Chetnik movement 1941-1945) and for centuries (the migrations of Serbian people in the Ottoman empire and then the former Serbian, but now declared as the Bosnian Diaspora in Turkey), all of which prevent a better understanding of the past, and thus the tracing of the movement towards the future.

We agree with authors who think we ought to be concerned about the claim that there are apparently so called "Ethno-Nationalist Identity Projects" in Serbia which are said to have focused on symbolic (re)affirmation and "recycling" of militant nationalist safety culture in social life and in the media during the transition process, which is also apparent in the TV film series "My cousin from the countryside." ${ }^{34}$ Its the plot is related to

\footnotetext{
${ }^{29}$ Todor Kuljić "Remembering Titoism: long shadows of the past", "Politika daily", Belgrade, Feulleton from a broader unpublished studies.

30 Jürgen Graf, "The myth of the Holocaust", Belgrade, "Zuhra", 2010, self-edition, 500 copies, Prohibited publication by the decision of the Higher Court in Belgrade.

${ }^{31}$ Jirgen Graf, "The myth of the Holocaust",, Chapter "Ness' Shirt".

${ }^{32}$ Russian President Medvedev's decree establishing the Special Committee for the Prevention of trying to falsify history to the detriment of Russia.

${ }^{33}$ After the events of September 11 in 2001 when happened the terrorist attacks in the United States, has been said that the world is not the same. The reaction of the world was the adoption of the Resolution of the Security Council of the United Nations no. 1373 September in 2001. State and Government Organizations and Institutions as well as relevant International Organizations such as the UN, OSCE, NATO and others established the forum for the coordination and facilitation of joint actions in the fight against global terrorism.

${ }^{34}$ Tijana Cvjetićanin, "Whose Cousin is "The Cousin from the Country"? Ideological read a media text", Center for Interdisciplinary Postgraduate Studies, Master Program: Gender Studies (2008/2010), University of Sarajevo, Bulletin of the Ethnographic Institute SASA, 2010, Vol. 58, № 1, p. 57-68, "...suggested that the
} 
the beginning of the transition process in Serbia to a stable democratic society, and the conflict with NATO and the political changes after October 5 th $2000 .^{35}$ If this is taken seriously in the research, it can lead to the conclusion that the assessed risk to society as said in that TV film series suggests that a major source of insecurity assumed dominance of pro - European civil and political options, not an Ethno nationalist right the wing of political parties that were advocated and defended as a ruling (from actors in the role of the military personnel in the film). The question is why not at least insist on the equality of the above mentioned policy options in the society? The lack of balancing democracy is obvious both in reality and in fiction art.

\section{Balancing Democracy}

In addition to the symbolic and institutional capacity building of the security system, as the first main reform proceedings, with a second course consisting of number of related issues of symbolic reform, there is a third, dynamic and contemporary public policy of most accessible set of activities to balance the official (military) and civilian sectors in Serbian society. It must be recognized that "true democracy still does not work in practice; however, the security situation and the process are under the jurisdiction of the state and its government, which themselves are the products of democratic elections." ${ }^{\text {"36 }}$ Now the elected politicians, commanding to the executive, are to promote the process of democratization and civilizing society. This simple fact indicates the dominance of the military sector in relation to the civil society sector, so it is necessary to balance the system of democratic policy in favour of civil society.

The European Union is trying to act in balancing democracy as their own, and in countries in transition and in turning processes of changing the history of the Balkan countries, however, "despite the pronounced political tool that handled the past, there are tensions, conflicts and competition between global policy and local memories and EU memories of Western and Eastern Europe." ${ }^{137}$ The term globalization has been replaced

\footnotetext{
"Anti-People Pro-Western Forces," after a change of Government, tried to set up the European Integration Process and that the main cause of the suffering of the main character, an intelligence officer that suddenly appeared in one Shumadia's village. Observed are two Negative Symbolic Approach to the transformation of our society into a democratic society with strong civil elements: the first in the social life of rural families, and then with all others in the field of Civil-Military Relations (CMR) all about the main character."

${ }^{35}$ Tijana Cvjetićanin, "Whose Cousin is "The Cousin from the Country"? Ideological read a media text": "Nationalist chants were turned to "clean" the Symbolic Space, spinning inside the simulacrum whose main Symbolic Activity - simultaneously calming and inciting "National Pride." Ethno- Nationalist autistic matrix repeats this cycle by talking to herself and the dropdown itself in the pursuit of "internal enemies desire": sensational stories (reviled soon as inaccurate) about the alleged request by the Chief Hague Prosecutor to a series to be banned because it promotes Anti-Hague values given by this identification a new momentum. Due to the inertia ... pure circulation but played no national story, and Local National Media Service became great refuge of hope, a hub of all Serbian illusions. (Savić, 2004: 7) http://www.glas javnosti.rs / article / week / glasjav nosti-26-04-2009/azdaha is disgusting forgery.

${ }^{36}$ Radoslav Gaćinović, "Democracy and Security in the national state, "Serbian Political Thought, № 1/2010. Year. 17, Vol. 27, p. 151-168;

${ }^{37}$ Todor Kuljić, , "Nationalism and glorious past," "Today daily," 2011, series of articles, "The memory of Titoism", "Politika daily", 2011, Feuilleton from unpublished studies from the broader "Remembering Titoism:
} 
by the concept of glocalization. G - local means localization of global trends and standards in the local national to local and national integration in global sense. This process essentially covers an area which should measure public or general interest that determines the path of reform of the security system.

Glocalization in the areas of preservation of national identity imposes bordering of national symbols, including the historiography involved in changes in historical memory in terms of overcoming the boundaries between existing national, regional and continental patterns of memories and their translation into the global memory, on which depend the correctness and wisdom of world politics. If we start from the premise that the public interest for the protection of the fundamental values of our society should be compatible with regional, continental and global interest, so that it can indicate that the risk factors for national security, it should be classified within a well-articulated and defined public interest. The most dangerous to our security compatibility with the region of South East Europe, the European Union and the World is emphasizing the national sentiments of belonging to a particular nation, over the feeling of belonging to a certain social stratum of the population and only a partial rejection of the authoritarian socialist system of government, so as to retain authoritarian party rule and the entire socialist social policy is rejected (as opposed to Sweden, Norway and Finland, where the situation is vice versa).

There are other alternative approaches to Symbolic Global Intelligence Community Reform and to the expansion of the security system, including the privilege of the great powers, or for "external use" of those powers. ${ }^{38}$ It is the approach that denies globalization or globalization is equated with violent Islam and converted to extreme Catholicism, neo-communism, neo-colonialism, occupation or any other form of ideological or factual subjugation. The emergence of globalization thesis that it has harmful effects on the natural expression of the search for serenity and happiness, politically-driven options. If superficially touches upon topics that would provide the basis for understanding the world as it is not vitally connected to the way it is for now empirically proven, and analyses the key positions of "anonymous authors" that might come from the intelligence and security communities and certain circles held by the academic community. We can notice that according to this concept the ethical basis for the standardization of human behaviour is generally alternatively sought in religion, so in this case it refers to some kind of the "Orthodox Church Way" (our comment), ${ }^{39}$ as a

long shadows of the past": "The countries affected by the transition far more defending national than socialist past. Thus by that they have encouraging the nationalist resistance to the processes of globalization, mutual interaction and hybridization affects to the image of the past. "

http://www.danas.rs/danasrs/feliton/procesi_globalizacije_uticu_i_na_slike_proslosti.24.html?news_id=204619;

${ }^{38}$ Group Anonymous authors Project, Russia , messages from the past - lessons for the future , - the three books Translator: Radoslav , Bosković , Editor: Nenad Djordjević ; Original title : Rossi Project , Academy for Diplomacy and Security , Public Official Gazette , Beogrd , 2009 three of " Project Russia " published by the Academy of Diplomacy and Security, 2005th year. "... What is a utopia? Political intrigue in the lobby of the parliamentary and presidential elections? Or prepare citizens for a new type of government in Russia? Judge for yourself ..."

http://www.vidovdan.org/index.php?option=com content\&view=article\&id=16614:projekat-rusija-ii-ta-nas-ekaposle-predsednikih-izbora-2012-godine\&catid $=\overline{41}$ : svet\&Itemid $=68$

${ }^{39}$ Project Russia, too, the second book, in the "Output ", p. 68. 
Theoretical Aspects of the Research to the Capacity of the Security System ...

global solution. However, when we look at the author's vision on how to achieve such a project, unfortunately, there is no mention of the management of knowledge, but rather of "human resources," nor of the knowledge diplomacy, but rather of a kind of (enlightened) absolutism. Some authors who were directly involved in the implementation of the concept of security system of the former Yugoslavia in countering attacks of NATO advocate for not changing the symbol of resistance and opposition to the matrix of external aggression and other types of threats to the security of the Republic of Serbia, describing then applied propaganda techniques, tactics and methods of NATO as enslaving and claim their counter - measures to be successful. ${ }^{40}$ The revolutionary defence doctrine in China has also considered similar concept that is based on the resistance to external influences, so there are observed similarities in terms of engagement "The Staff: .... millions of successors of proletarian revolution," but this kind of security systems can be imagined only by the great powers.

\section{Conclusion Appendix of Transformation of the Security System of the Present Security - Intelligence State into the System of Democratic State}

The shift from time intelligence and security state as an authoritarian model to model in accordance with the times of democracy with a strong influence of civil institutions (we would say the "red shift" exactly substantial for society as it is in the astronomy within the changes in the light spectrum due to the influence of the speed of moving the galaxies) is the key factor in increasing the capacity of the security system and it is based on the assumption that in established democracies this transformation process is usually already enabled so that there are controlled domestic security agencies, such as the Federal Bureau of Investigation (FBI) in the United States or, for example, the security services in the UK (MI5) performing some counter-intelligence work. That was not the case in authoritarian regimes. A feature of threat to a security system is that the boundaries and functions of security agencies and police organizations overlapped or did not differ much from each other.

Typical authoritarian regimes have relied upon organizations that are mainly engaged in the identification of domestic opponents/enemies (category "internal enemies") and neutralizing the opponents of their government, and, in many ways, affixed media under control and created, if not the desired level of security, the state of apathy in the society. In authoritarian regimes, the threats were in most cases organized by the security services. It was because of the heavy reliance of the government on these organizations and their staffs that the security apparatus grew in size and power, with the result that it was often self-managed, independent and even within authoritarian regimes themselves. In these countries, the role of security agencies was to protect state secrets from external threats, meaning from anyone who was outside the centre of political power.

\footnotetext{
${ }^{40}$ Goran Matić, “U milosti anđela”, Media Graf, Beograd, 2005, Lexicon propaganda, str. 329, Goran Matic, "The angel of mercy," MEDIAGRAF, Belgrade, 2005, Lexicon of propaganda, p. 329;
} 
And since it was in these conditions, almost all of those out of the centre of power could be defined as state secret enemies and had to be be controlled, and so the scope of what had to be brought under control was huge. Although in most cases the security services rhetorically linked the internal opponents of the regime to alleged foreign enemies, and it is beyond doubt that the focus of their work - the focus of security agencies in most authoritarian regimes was domestic opposition, not opposition or defence of other countries.

Deviations in the distribution of power consist of the facts that these security agencies functionally operated more like a "political police" than domestic intelligence institutions. Over time, they gained greater autonomy from politics and became isolated from any type of testing. They gathered political influence and inevitably gathered intelligence about a huge number of people, including legislators and the judiciary (if they existed as an independent power in the system of separation of powers), although much of the information was usually not associated with a particular criminal offense. It is suggested that a scientific analysis of the research carried out in countries such as Argentina, Brazil, Romania, South Africa, Taiwan. In these cases, authoritarian security agencies were created in what some authors call an independent security system of the state as an extreme form of security intelligence organization that is characterized by the absence of any external control of intelligence activities.

If the elected government does not control the intelligence services, it is by definition not a consolidated democracy. We think this is important because democratic consolidation requires a culture of democracy in the institutions as well. Legitimacy has the central place in the security culture. It is clear that if the government does not monitor and control services, it is likely that if certain intelligence activities are not precisely defined, then the legitimacy of the government has to be limited. We believe that the confidence of the citizens in the institutions of democracy will never be achieved unless the question posed involving this fundamental rule is resolved. With backward intelligence behind the authoritarian regimes that were in fact government oversight, the trust can never be achieved. Democratic consolidation is a major challenge, even in the best of circumstances, let alone after the political collapse of a security system. In transition in many countries, the greatest social and economic disadvantage, especially one that is as critical, characterized by the political regimes of North Africa, is the lack of legitimacy of the government. It is one of the obstacles that occur in such transitions that is an obstacle impossible to overcome, because the most stable democracies have "overwhelming control over Intelligence Community in the executive branches of the government," and we would add: it is impossible, but just without thinking and scientific research.

The effectiveness of security - Intelligence Community in societies in transition should be in accordance with the efficiency that is achieved at the level of the international intelligence community. There is a hypothesis that almost everywhere in democracies "that have been established to a greater extent," there is a separation in treatment between different organizations within the international community. Coordination of these agencies is a major challenge to democracy in ensuring the effectiveness of their intelligence communities (IC). Of course, the problems are the obstacles to coordination among agencies. Such barriers occur due to bureaucratic 
Theoretical Aspects of the Research to the Capacity of the Security System ...

obstacles in normal inter-departmental cooperation, such as greens and protection and fight for resources. In the specific context of the concept of the intelligence community IC, these obstacles have tremendously magnified and multiplied its unique characteristics, all of which stem from the need to work in secret, leading to concerns in providing its products to other organizations that could not be kept secret. An additional factor is the competition among organizations for sale of product information to the users, which is ultimately under the competence of policymakers.

The hypothesis is that in societies in transition, this research can be used to change goals and capacity of the whole system of security in case of new democracies as part of the overall process of democratic consolidation. So it is even present within the increased emphasis on efficiency in more established democracies (US, UK, etc.). Still, among them is a problem with the democratic, civilian control. We must continue to bear in mind that it is simply inherent in the nature of intelligence as a process and as an organization, and that these relationships are still troubled. However, democracy as a system of government is based on the responsibility of governments to manage. On one hand are the requirements of transparency, on the other hand, the system of security and confidentiality of the service requests. There is constant tension and dilemma in the design and management of security and intelligence community - IC, which is reflected in the democratic civilian control and effectiveness. Knowledge of how to deal with this dilemma remains the biggest challenge in new democracies in the field of security systems. The same institutional question remains unanswered: who will send a message to the Government?

\section{Literature}

[1] Kofi, A Annan: Two Concepts of Sovereignty (The Economist: 18th September 1999), http://www.un.org/Overview/SG/kaecon.htm> (01/19/2000).

[2] Dimitrijević, Vojin: Social and Cultural Prerequisites for Promotion and Implementation of the Democratic Control of Armed Forces (Geneva: Centre for the Democratic Control of Armed Forces (DCAF), Working Paper Series N67), 2002.

[3] Gajić Glisić, Dobrila: From the office of Minister of War, Serbian army (Čačak: 1993 Litopapir), 30.

[4] Fischerm, Vladimir: The Role of Dositej Obradovic in the Construction of Serbian Identities During the 19th Century, http://www.yorku.ca/soi/Vol_3/_HTML/Fischer.html.

[5] Fukuyama, Francis: The End of History and the Last Man (Podgorica: 1999 CID).

[6] Gaćinović, Radoslav: Democracy and Security in the Nation - State (Serbian Political Thought: 2010, №1), 151-168.

[7] Alexandre Lambert, "Implementation of democratic control of armed forces in the OSCE Region: Lessons Learned from the OSCE, Code of Conduct on Politico - Military Aspects of Security", Geneva Centre for the Democratic Control of Armed Forces (DCAF), Occasional Paper №11, Geneva (July 2006).

[8] Glossary of Security Culture, Centre for Civil - Military Relations, Belgrade 2009.

[9] Matic Goran: The angel of mercy (Belgrade: 2005 Mediagraf, Lexicon of propaganda), 329.

[10] Hannah Greg, O'Brien Kevin A and Rathmell Andrew, RAND Corporation: Intelligence and Security Legislation for Security Sector Reform (Report was prepared for the UK's Security Sector Development Advisory Team), htpp:// www.rand.org 
[11] Jürgen, Graf: The myth of the Holocaust (Belgrade: 2010 Zuhra self-edition, Prohibited 500 copies publication by the decision of the Higher Court in Belgrade).

[12] Matić, Goran: The Angels of Mercy (Belgrade: 2005 Mediagraf), 344.

[13] Bjeloš, Maya: What are the citizens thinking of their own security and the security of Serbia? (Belgrade Centre for Security Policy: 2010 BCSP April and May, the Research in Cooperation with CeSID).

[14] Military Security Agency, Chronology of the Security Service in the Army, http://www.mod.gov.rs/lat/organizacija/vba/vba_istorijat.php

[15] Ekmečić, Milorad: The long movement between slaughter and plowing, A History of Serbs in the New Century (Belgrade: 2007 Textbook from the display by Staniša Nesić1492-1992), 600.

[16] Milosavljević, Zoran T: "The role of the global political community in the preservation of world peace," (Master thesis, University of Belgrade, Faculty of Political Science 2009).

[17] Jevtić, Miroljub, S.: Orthodoxy and the Serbian National Identity(Serbian Political Thought:1998 Vol. 5, N¹-4), 63-78.

[18] Zeman, Petar: The Transformation of the Intelligence Services, Transformation - Czech Experience (Prague: 2006 Hugo Printing Company), 115.

[19] Resurrection Serbian state: political-historical study of the first Serbian uprising (1804-181) 13, 80.

[20] Simeunović, Dragan: The Battle of Kosovo and Metohija - the history, current situation and perspectives, military action (Belgrade: 2000 Military Review, Vol.52, №1), 16-39.

[21] Simeunović, Dragan: Definition of extremism from the perspective of political theory (Serbian Political Thought: 2009Vol. XVI Vol 24, N²), 15.

[22] Andrija BK Stojković: Life Path Dositeja Obradovic (Belgrade: Beletra).

[23] Basara Svetislav: the Famous Emperor's old clothes (Daily: 2009 Basara).

[24] C. Thomas Bruneau and Steven C. Boraz, "Reforming Intelligence Obstacles to Democratic Control and Effectiveness", Establishing democratic control of intelligence services in Argentina (Priscila Brandão Carlos Antunes), 195.

[25] Cvjeticanin, Tijana: Whose Cousin is the Cousin from the Country? (University of Sarajevo: Center for Interdisciplinary Postgraduate Studies, Master Program of Gender Studies, Ideological read a media text 2008/2010, Bulletin of the Ethnographic Institute SASA, 2010, Vol . 58, N01), 57-68.

[26] Weiner, Tim: "Legacy of Ashes: The History of CIA", (New York: 2007 Doubleday Publishing Group Random House, Inc., General William J. Donovan: from the letter addressed to the US President Roosevelt in November 18th 1944).

[27] Kuljić Todor: Politika daily (2011: Feuilleton from the broader unpublished studies, Remembering Titoism: long shadows of the past).

[28] UN Development Programme (UNDP): New York: 1994 Oxford University Press, UN Human Development Report), 3.

[29] Draganić, Johnston, Alastair: Youth's security culture, how to live safely (Belgrade: 2006 International Security, Thinking about Strategic Culture, 1995 Vol. 19, №4).

[30] Katzenstein, J. Peter: Culture of National Security: (New York: 1996 Columbia University Press), http://www.scribd.com/doc/19945269/pojmovnikbezbednosnekulture. 